\title{
Determinants in detecting fraud triangle of financial statements on companies registered in Jakarta Islamic Index (JII) period 2012-2018
}

\author{
Iwan Budiyono, ${ }^{1}$ Melati Sari Dewi Arum ${ }^{2}$ \\ 1,2Politeknik Negeri Semarang, Indonesia \\ email: iwan.budiyono@polines.ac.id
}

\begin{abstract}
Purpose - The purpose of study was to examine the effect financial statement fraud based on the fraud triangle with a number of variables such as financial stability, external pressure, financial target, personal financial needs, opportunity and rasionalization in companies listed in Jakarta Islamic Index(JII) period 2012-2018.
\end{abstract}

Method - The population are all companies listed in JII period 2012-2018. The sample is 6 companies that were feasible to analyze. The data used in this research is secondary data obtained from the annual report. The data analysis model applied multiple linier regression data panel using SPSS 25.

Result - The results showed that the fraud triangle in the categories of financial stability, external pressure, financial targets, personal financial needs, opportunity and rationalization simultaneously affect the fraudulent financial statements. Furthermore financial stability, personal financial needs and opportunity partially negatively related and had no significant effect on financial statement fraud; while external pressures, financial targets and rationalization have positive and significant effects on financial statement fraud on companies listed in JII period 2012-2018.

Implication - Companies Registered in JII are suggested to improve the financial performance in accordance with sharia principles.

Originality - This research is the first study using multiple linier regression data panel.

Keywords: financial stability; external pressure; personal financial needs; fraudulent financial statements 
Iwan Budiyono, Melati Sari Dewi Arum

\section{Introduction}

Companies generally provide information to the users as a form of communication between the owner and manager of the company. JIAFR | 118 Information users are divided into two parties, namely the internal and external parties. Internal party includes management, owners, and employees of the company, while the external parties are investors, creditors, suppliers, customers, government and the public (Mulyadi, 2013). It makes information important for many people, causing fierce competition to expand market share. Normal market share expansion happens in the stock market, which is a place to exchange or negotiate commodities in the form of capital that will be used to improve company performance. According to Mulyadi (2013), for the investors, companies must display company information with the best performance, in which information is disclosed in the form of reliable financial statements.

The financial manager is responsible for making important decisions about investing and making. Therefore, Zimbelman et al. (2014) said that the big responsibility of manager makes manager do everything they can to enhance their financial statements so that companies can compete with other companies. It is the result of financial statements.

According to the ACFE Certified Fraud Examiners Association (2016), fraud does not only occur in financial statement. Based on the results of the ACFE survey (2016), fraud in the financial statements became one of the most types of fraud chosen by respondents by $4 \%$. This difference is caused by the respondents' different knowledge and experience because of the number of publications on corruption. The results of this questionnaire are different from the survey conducted by ACFE (2016) which states that financial statement fraud is the most detrimental.

The results of the 2016 ACFE survey above only presents $4 \%$, but the amount of loss caused depends on the level of more than Rp 10 billion. It is supported by the results of a survey conducted by ACFE (2016), where the biggest losses came from fraudulent types of financial statement fraud of $\$$ 
$1,000,000$. This result is supported by data released about fraudulent financial statements being one of the scams that took a long and difficult detection. Therefore, companies and the state cannot fully think of the losses incurred.

The fraud triangle is a fraud detection of financial statements included in the section 316 audit standard adopted from Cressey's concept (1953). It contains pressure, opportunity, and rationalization. Pressure is a situation when someone feels pressured/depressed by a heavy condition when someone faces difficulties. Pressure can consist of certain targets set by the company. If the manager cannot meet the target, the success of his career will be questioned. This has an impact on managers to do various ways so that targets are met by manipulating financial statements. The second factor causing someone to cheat is opportunity. Opportunity or chance is, for example, when someone or manager is cheating because he has an opportunity. This opportunity can be in the form of opportunities to make fraud. Opportunities for cheating can occur due to several considerations: avoid oversight from the board of directors, reduce the company's ability to improve performance, adjust schedules with others and increase the audit trail that supports fraud. The third factor is the realization or justification of the crime facts. Rationalization or justification means someone who can be justified for his acts of fraud. This justification is, for example, protests against fraud for companies, keeps shares high, or can also question the need to protect shareholders (Zimbelman, et al., 2014).

\section{Literature Review}

\section{Agency Theory}

Agency theory describes the relationship between principal and agent, where the principal gives mandate to the agent to perform some service on behalf of the principal that involves some decision making authority to the agent. The logical consequence of this employment contract is to improve efficiency by reducing the role of information loss caused by the moral hazard problem. People who use the agency theory will see the maximum benefits 
Iwan Budiyono, Melati Sari Dewi Arum

individuals where each individual is motivated by their own interests than the others' interests. The difference is this interest can lead agency problems that affect the quality of reported earnings (Jensen and Meckling, 2017).

JIAFR | 120 Stewardship Theory

Stewardship theory is a theory that describes the situation where the manager is not motivated by the goals of individuals but rather indicated the main objectives for the benefit of the organization. According to Donaldson and Davis' (1991) basic theory of psychology and sociology, a stewardship is designed where the executive as steward is motivated not to act according to the wishes of the principal. In addition, someone with steward behavior will not leave the organization because the steward tries to reach the organization target. His desire to meet the target set by the company owner can trigger a strong desire to achieve the objectives of the organization in any way as manipulating financial statements to increase the investors' interest. It is because bad financial statements can prevent investors from investing to a company (Raharjo, 2007).

\section{Jakarta Islamic Index}

According to Nafik (2009) the Jakarta Islamic Index (JII) is a stock index based on sharia principles. Shares in JII consist of 30 shares which will be regularly reviewed regarding the distribution of funds on the stock exchange, its financial ratios, and compliance based on sharia principles outlined in the National Sharia Board Fatwa No. 05/DSN-MUI/IV/2000 concerning capital markets, as well as guidelines for the Application of Sharia Principles in the Capital Market Sector. Shares that can be included in JII must meet the requirements as written in the National Sharia Council Fatwa Board of Indonesian Ulema No. 20/DSN-MUI/IV/2001 concerning Investment Implementation Guidelines for Sharia Mutual Funds.

Companies registered in JII must go through regulations, one of which is written in the National Sharia Council Fatwa Council Fatwa No. 20/DSNMUI/IV/2001 concerning Investment Implementation Guidelines for Sharia 
Mutual Funds Chapter IV (Article 9) speculation which contains uns gharar. The agreed actions are: (1) Najsy, which is making a fake offer, (2) Ba'i alMa'dum, which is selling goods that have not been approved, (3) Insider Trading, which is disseminating misleading information or using inside information to obtain purchase transactions that are issued, (4) Invest in a company that at the time of the level (ratio) of their debts are more dominant than their capital.

Based on the explanation of the prohibition in companies listed in JII, there is no need to do earnings management (fraudulent financial statements) because it is tantamount to causing gharar or unclearness in the financial statements submitted not in accordance with the reality.

\section{Fraudulent Financial Statements}

The financial report is an overview of financial position and financial performance of an organization that is very important because it reveals how the former, the current, and the future employers' work. The financial statements are presented with integrity, and fair in accordance with Generally Accepted Accounting Principles (GAAP). Financial statements are important to reveal the condition of organizations that gives an impact on their misstated financial statements either intentionally or unintentionally. Intentionally misstated the financial report will indicate the financial statement fraud. Changes made may advertently be an act of cheating if someone does it is aware of the misstatement and does not provide justification in the financial statements (Zimbelman et al., 2014).

According to Statement of Audit Standards (SAS) No. 99, cheating financial statements can be done with several actions, namely: (1) Manipulation, falsification, or changes in accounting records, supporting documents from the compiled financial statements, (2) Mistakes or negligence in significant information on financial statements, (3) Deliberately misuse the principles relating to number, classification, method of presentation, or disclosure. 
According to Rezaee (2002), financial reporting contains accountable fraud, financial information and can affect various parties such as owners, creditors, employees, auditors, and even competitors. Therefore, financial reductions are used by companies that reduce finance and are motivated by misguided opportunism.

\section{Factors That Affect Financial Statements}

According to the theory known in the ranks or the police profession in Ardianingsih (2018: 79), the factors that influence fraud are based on the theory of $\mathrm{C}=\mathrm{N}+\mathrm{K}$, that Criminal $(\mathrm{C})$ is the same as Intention $(\mathrm{N})$ and Opportunity (K). This theory states that there is an intention to commit fraud; however, if there is no chance there will be no fraud. Opportunity is owned by people or groups who have authority and access to fraud. The intention to act is determined by morals and integrity.

\section{Fraud Triangle}

Cressey (1953) introduces a fraud triangle that can be used to prevent fraud. Three elements that are the cause of fraud can be seen in Figure 1.

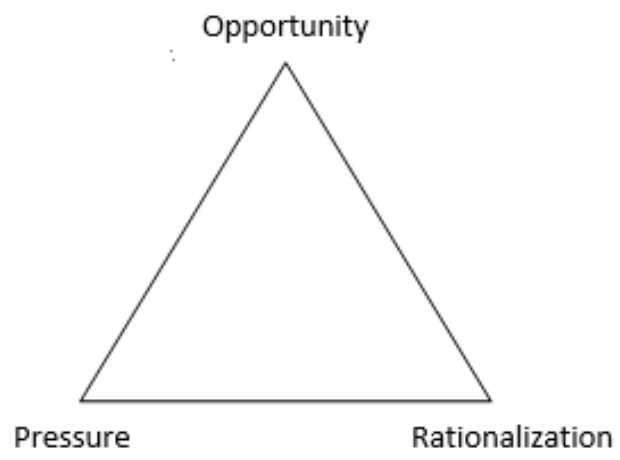

Figure 1. Fraud Triangle

Source: Cressey (1953), Skousen, et al. (2009), Zimbelman, et al. (2014), Abdullah and Manasor (2015), Tiffani and Marfuah (2015), and Utomo (2018) 
Determinants in detecting fraud triangle of financial statement on ...

\section{Pressure}

Pressure has various meanings, it is a situation where someone is in control/depressed by conditions when someone overcomes difficulties. This meaning shows the pressure that can drive someone to commit acts of fraud (Ardianingsih, 2018). According to Auditing Standard Section 316, there are four types of general under pressure conditions in which fraud can occur. These conditions are financial problems, external pressures, personal financial needs, and financial targets.

In accordance with SAS No. 99, it is a state that describes the company's stable financial condition. The company's financial condition is considered stable if the company can meet the routine needs. The needs will come to a sudden financing needs though. When a company is in a stable condition, the value of the company will rise in the view of investors, creditors and the public. Therefore, managers will do everything possible so the financial stability of the company looks stable.

External pressure is excessive pressure for management to meet the requirements or expectations of third parties that may lead to fraud. The pressure can be shaped in terms of the ability to obtain loans from outside the company as well as the ability to repay the loan (Skousen et al., 2009).

Financial targets are excessive pressure on management to achieve the financial targets set by the board of directors or management. Examples of risk factors: companies may manipulate earnings to meet estimates or benchmarks analysts as the previous year's profit. Financial targets are a condition in which the company's profit rate that has been set must be obtained for the effort made.

Personal financial needs are a situation where the company's finance is also influenced by the financial condition of the company's executives (Skousen et al., 2009). In addition, according to Beasley (1996), when the company's executives have a strong role in the company's financial, personal financial needs of the company executives will also be affected by the company's financial performance. 
Iwan Budiyono, Melati Sari Dewi Arum

\section{Opportunity}

The existence of the opportunity allows fraud. Opportunities are created by industrial conditions (nature of industry) that have weak monitoring. It JIAFR | 124 can be used as an opportunity by the agent or management to commit fraud in the financial statements.

\section{Rationalization}

Rationalization of the essential elements of fraud occurs when the actors try to justify their actions (Ardianingsih, 2018). For those who are not accustomed to be honest, will probably be easier to rationalize cheating. The behavior of top management related to the financial reporting process is a critical factor in the assessment of the likelihood of fraudulent financial reporting that contain fraud.

\section{Previous Research}

Past research about factors of financial statements fraud detection have been made by some researchers, one of which is Skousen et al. (2009) who state that five (5) proxies of pressure and two (2) proxies of opportunity have a significant effect on the financial statements fraud, while rationalizing has no significant effect on the financial statements fraud.

Tiffani and Marfuah (2015) state that pressure by proxy ACHANGE and LEV has a significant effect on the financial statement fraud, pressure by proxy OSHIP and ROA has no significant effect on fraudulent financial statements, and opportunity significantly influences the proxy receivable fraudulent financial statements.

Widarti (2015) states that pressure by proxy ACHANGE and ROA has a significant effect on the financial statement fraud, while the proxy OSHIP pressure has no significant effect on the financial statements fraud.

Susianti and Yasa (2015) state that pressure by proxy ACHANGE and fraud ROA significantly influence the financial statements, proxy receivable opportunity significantly influences the financial statement fraud, and 
pressure by proxy OSHIP and LEV has no significant effect on the financial statements fraud.

Umarsono (2016) states that pressure by proxy ROA and rationalization has a significant effect on fraudulent financial statements, while the opportunity to proxy receivable has no significant effect on the financial statements fraud.

Purba and Putra (2017) state that pressure on ACHANGE and ROA proxies does not significantly influence financial statement fraud, pressure with LEV proxy had significant effect on financial statement fraud, and reformation with TACC proxy is not significant on financial statement fraud.

Tunjungsari et al. (2018) state that pressures with ACHANGE proxies do not have a significant effect on financial statement fraud, pressures with proxies (LEV and ROA) and analysis with TACC proxies had a significant effect on financial statement fraud.

\section{Hypothesis Development}

\section{The Relationship between Financial Stability and Financial Statement Fraud}

Management is faced with pressures in carrying out financial statements since financial arrangement is threatened by unexpected financial and industrial conditions. It is because financial instability is a condition that raises problems experienced by companies that might be used by management to manipulate financial statement (Skousen et al., 2009).

It is corroborated by Tiffani and Marfuah's research (2015) that discuss the change in total assets (ACHANGE) has a positive effect on financial statement fraud. Other researches were conducted by Windarti (2015) and Susianti and Yasa (2015) stating that the ACHANGE proxy plays a significant role in the detection of financial statement fraud.

$H_{2 a}:$ Factor pressures with financial stability category which is proxied by the percentage change in total assets (ACHANGE) is partially positive and has a significant effect on the financial statements fraud. 
Iwan Budiyono, Melati Sari Dewi Arum

\section{The Relationship between External Pressure with Financial Statement Fraud}

External pressure is no urgency for management to meet the wishes or desires of a third party. According to the Auditing Standards Section 316 JIAFR | 126 when the excessive external pressure is the case, then there is a risk of fraud on the financial statements. It is supported by Skousen et al.'s research (2009) which states that the percentage of total debt to total assets (LEV) has a positive significant effect on the financial statements fraud.

$H_{2 b}$ : Pressure factors with external categories which are proxied by leverage (LEV) have a positive and significant effect on financial statement fraud.

\section{The Relationship between Financial Targets and Fraudulent Financial}

Statements

According to the Auditing Standard Section 316 financial targets are higher for management to achieve financial targets set by directors or management, including the goals of intensive acceptance of sales or profits. Skousen, et al., (2009) say that Return on Assets (ROA) is often used in improving the manager's performance and in determining bonuses, wage increases, and others. Using ROA is used as a proxy for financial target variables in this study. It is supported by Widarti (2015), Susianti and Yasa (2015) and Umarsono's researches (2016) which state that the financial targets by proxy ROA has a significant effect on the financial statements fraud.

$H_{2 c}:$ Factor pressure with a financial target category proxied by the percentage return on assets (ROA) is partially positive and has a significant impact on the financial statements fraud.

\section{The Relationship between Personal Financial Needs with Financial Statement}

Fraud

Personal financial needs is a condition where the company's finance is also influenced by the financial condition of the company's executives (Skousen et al., 2009). In addition, according to Zimbelman et al. (2014: 46- 
47), this personal requirements arise from the nature of greedy corporate executives who take advantage of the strong economic system, various lucrative deals and high profits of a company. It is supported by research conducted by Skousen et al. (2009) which shows that the personal financial needs proxied by the percentage of ownership by insiders (OSHIP) has positive effects on the financial statements fraud.

$H_{2 d}$ : Factors pressure with the personal financial needs category proxied by stock ownership by insiders (OSHIP) partially has a positive and significant impact on the financial statements fraud.

\section{The Relationship between Nature of Industry with Financial Statement Fraud}

According to Audit Standard Section 316, fraudulent financial reports on the company can be minimized by a good oversight mechanism. It can be done by observing a number of frauds in the study sample involving receivables as one of the opportunities for agents or managers in fraudulent manipulation of financial statements.

This view is supported by research conducted by Skousen et al. (2009) that the nature of the industry has a significant positive effect on the financial statements fraud where the nature of the industry is proxied by the ratio of receivables (receivables).

$H_{3}: \quad$ Factors of opportunity of nature of industry category (receivable) is partially positive and has a significant effect on the financial statements fraud.

\section{The Relationship between Rationalization of Cheating and the Financial}

\section{Statements}

Rationalization is a form of justification of a criminal or fraud as something acceptable. The form of this rationalization may be thinking that the management should make protection of shareholders and keep the stock prices high (Zimbelman et al., 2014: 43). 
Iwan Budiyono, Melati Sari Dewi Arum

The view above is corroborated by Umarsono's research (2016) which states that rationalization has a significant effect on the financial statements with a proxy fraud total accruals (TACC).

JIAFR | 128

$\mathrm{H}_{4}$ : Factor rationalization by proxy the ratio of total accruals and total assets (TACC) is partially positive and has a significant effect on the financial statements fraud.

\section{Research Methods}

According to Ferdinand (2014: 172), participation is a collection or an element that has certain information desired by researchers and the results will show different conclusions for these groups or population. The population used in this study is companies registered in the Jakarta Islamic Index (JII) for the 2012-2018 period.

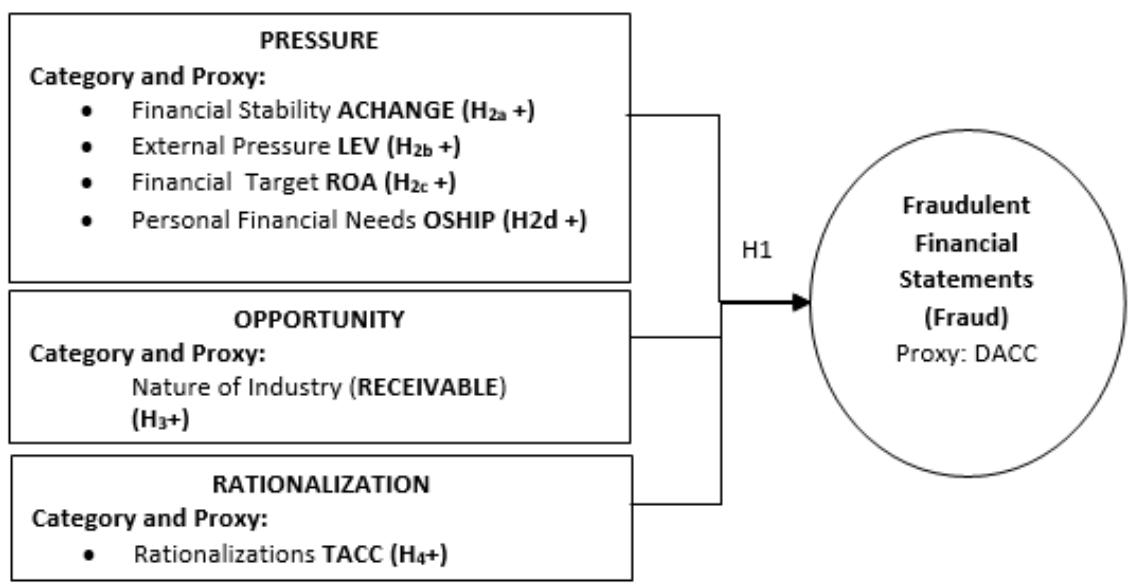

Figure 2. Theoretical Framework

Source: Skousen et al., (2009), Widarti (2015), Susianti and Yasa (2015), lqbal and Murtanto (2016), Wahyuni (2017), Pasaribu and Karisma (2018) 
To take the samples, this study used purposive sampling, which is a sampling technique based on specific objectives. Sampling was done by determining the criteria for the sample to be taken. Sample criteria used in this study include: (1) Companies registered in the Jakarta Islamic Index (JII), (2) Companies listed on the Jakarta Islamic Index (JII) during the 2012-2018 period, (3) Companies that present annual reports on the company's website or the IDX website during the 2012-2018 period, (4) Company annual reports have data relating to research variables, (5) The company's financial statements are not presented in foreign currencies.

Samples were obtained from 6 (six) companies or 42 data. The data in this study were taken from the company's financial statements included in the Jakarta Islamic Index (JII) during the 2012-2018 period, both in the form of annual reports (annual reports) and in the form of financial reports (financial statements).

The variables in this study consisted of the dependent variable (Y), which is the financial balance proxied by earnings management and the independent variable (X), namely pressure with a proxy ACHANGE, LEV, ROA and OSHIP. While other independent variables are opportunities that are proxied by accounts receivable ratios (DUE) and rationalizations that are proxied by discretional accrual ratios (DACC). The operational definitions of each variable can be seen in table 1.

Table 1. Definition of Operational Variables

\begin{tabular}{|c|c|c|c|c|c|}
\hline No & Variable & $\begin{array}{c}\text { Definition of } \\
\text { Operational } \\
\text { Variables } \\
\end{array}$ & Measurement & Unit & Scale \\
\hline 1. & $\begin{array}{c}\text { Profit } \\
\text { management } \\
\text { (DACC) }\end{array}$ & $\begin{array}{l}\text { Actions according } \\
\text { to earnings } \\
\text { according to the } \\
\text { will of the } \\
\text { company's } \\
\text { management } \\
\text { (Fahmi, 2012: } \\
\text { 281) }\end{array}$ & 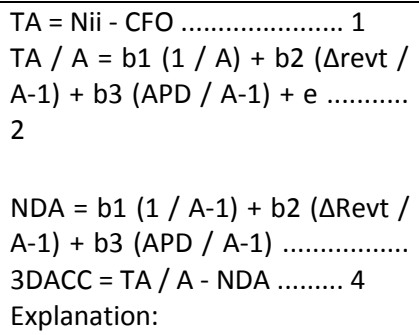 & Decimal & Ratio \\
\hline
\end{tabular}


TA: Tot. Accrual

Nii: Net Profit

CFO: Cash Flow from Operations

NDA: Non Discretionary Accrual

DA: Discretionary accruals

A-1: Total asset period previously

$\triangle$ revt: Change in net sales

APD: Property, factory, dan

Equipment

\begin{tabular}{|c|c|c|c|c|c|}
\hline 2. & $\begin{array}{c}\text { Financial } \\
\text { stability } \\
\text { (ACHANGE) }\end{array}$ & $\begin{array}{l}\text { Financial picture } \\
\text { of the company } \\
\text { in a stable } \\
\text { position (SAS No. } \\
\text { 90). }\end{array}$ & $\begin{array}{l}\text { ACHANGE }=\frac{\text { Total Asset }_{\mathrm{t}}-\text { To }}{\text { Total As! }} \\
\text { Explanation: } \\
\text { ACHANGE: Change asset }\end{array}$ & Decimal & Ratio \\
\hline 3. & $\begin{array}{c}\text { External } \\
\text { Pressure (LEV) }\end{array}$ & $\begin{array}{l}\text { Pressure from } \\
\text { third parties that } \\
\text { reduces fraud } \\
\text { (Skousen et al., } \\
\text { 2009) }\end{array}$ & $\begin{array}{l}\text { LEV }=\frac{\text { Debt Total }}{\text { Total Assets }} \\
\text { Explanation: } \\
\text { Leverage }: \text { debt ratio }\end{array}$ & Decimal & Ratio \\
\hline 4. & $\begin{array}{c}\text { Financial } \\
\text { Target (ROA) }\end{array}$ & $\begin{array}{l}\text { Company } \\
\text { provisions for } \\
\text { approval of } \\
\text { return on income } \\
\text { (Audit Standard } \\
\text { Section 316). }\end{array}$ & $\begin{array}{l}\text { ROA }=\frac{\text { Profit Before Tax }}{\text { Total Assets }} \\
\text { Explanation: } \\
\text { ROA: Return On Asset }\end{array}$ & Decimal & Ratio \\
\hline 5. & $\begin{array}{c}\text { Personal } \\
\text { financial needs } \\
\text { (OSHIP) }\end{array}$ & $\begin{array}{l}\text { Corporate } \\
\text { finance executive } \\
\text { Financial } \\
\text { condition of } \\
\text { executives } \\
\text { (Skousen et al., } \\
\text { 2009) }\end{array}$ & $\begin{array}{l}\text { OSHIP }=\frac{\text { Shares owned by the }}{\text { Amount of common }} \\
\text { Explanation: } \\
\text { OSHIP: Ownership (insider } \\
\text { shares) }\end{array}$ & Decimal & Ratio \\
\hline 6. & $\begin{array}{l}\text { Opportunity } \\
\text { (ACCEPTED) }\end{array}$ & $\begin{array}{l}\text { Opportunities } \\
\text { about the } \\
\text { possibility of a } \\
\text { decline in finance } \\
\text { (Skousen et al., } \\
\text { 2009). }\end{array}$ & $\begin{array}{l}\text { RECEIVABLE }= \\
\frac{\text { RECEIVABLE } t}{\text { SALESt }}-\frac{\text { RECEIVABLE } 1}{\text { SALES } t-} \\
\text { Explanation: } \\
\text { RECEIVABLE: ratio of accounts } \\
\text { receivable }\end{array}$ & Decimal & Ratio \\
\hline 7. & $\begin{array}{l}\text { Rationalization } \\
\text { (TACC) }\end{array}$ & $\begin{array}{l}\text { Justification for } \\
\text { cheating } \\
\text { (Ardianingsih, } \\
\text { 2018: 80). }\end{array}$ & $\begin{array}{l}\text { TACC }=\frac{\text { Total Accruals }}{\text { Total A ssets }} \\
\text { Explanation: } \\
\text { TACC: Total Accruals }\end{array}$ & Decimal & Ratio \\
\hline
\end{tabular}

Source: Fahmi (2012), SAS No. 90, Skousen et al. (2009), Audit Standard Section 316, and

Ardianingsih (2018)

Journal of Islamic Accounting and Finance Research - Vol. 2 No. 1 (2020) 
Determinants in detecting fraud triangle of financial statement on ...

\section{Results and Discussion}

Descriptive Statistics based on the results of data processing using SPSS 25.00 can be seen in table 2 .

The Classical Test consists of the normality test, the Multicollinearity Test, the Autocorrelation Test and the Heteroscience Test. The results of the normality test using a plot probability graph show normal distribution graphs and Kolmogorof Smirnov shows a significance value of 0.113 . Multicollinearity test results show that tolerance has a value of more than 0.10 , and a VIF of less than 10 . It shows that there is no multicollinearity between independent variables whose values are more than $95 \%$. Autocorrelation indicates probability or Asym. Sig. (2-tailed) of 0.160 or greater than the 0.05 significance. Thus it can be concluded that the model is free from autocorrelation. And Heteroscedasticity Test results show the significance of all independent variables is not statistically significant or it is greater than 0.05 or equal to 0.05 . So, it can be concluded that the regression model is free from heteroscedasticity results.

\section{Hypothesis Test Result}

Proof of hypothesis 1 (one) is done by the $\mathrm{F}$ test. Based on table 3, the results are $\mathrm{F}$ count $=19,000>\mathrm{F}$ table $=2.48$ or a significance of $0,000<0.05$, which means in accordance with the significant influence between ACHANGE, LEV, ROA, OSHIP, RECEIVABLE and TACC simultaneously against DACC. Thus, hypothesis 1 (one) which states "Fraud Triangle simultaneously has a significant effect on Fraudulent Financial Statements in companies listed in the Jakarta Islamic Index (JII) for the 2012-2018 period" is accepted.

\section{Partial Regression Coefficient Test (t Statistical Test)}

The result of the partial coefficient analysis with the t-test statistic can be seen in table 4. 
Iwan Budiyono, Melati Sari Dewi Arum

Table 2. Descriptive Statistics

\begin{tabular}{lccccc}
\hline \multicolumn{5}{c}{ Descriptive Statistics } \\
\hline & $\mathrm{N}$ & Minimum & Maximum & Mean & Std. Deviation \\
ACHANGE & 42 &, 01 &, 29 &, 1101 &, 06737 \\
LEV & 42 &, 16 &, 64 &, 3925 &, 12303 \\
ROA & 42 &, 03 &, 19 &, 1115 &, 04540 \\
OSHIP & 42 &, 00 &, 01 &, 0012 &, 00233 \\
RECEIVABLE & 42 &, 07 &, 34 &, 1815 &, 07171 \\
TACC & 42 &,- 15 &, 17 &,- 0240 &, 07024 \\
DACC & 42 &,- 11 &, 26 &, 0309 &, 06614 \\
Valid N (listwise) & 42 & & & & \\
\hline
\end{tabular}

Table 3. F Statistical Test Result

\section{ANOVA $^{\mathrm{a}}$}

\begin{tabular}{llccccc}
\hline Model & & Sum of Squares & Df & Mean Square & F & Sig. \\
\hline 1 & Regression &, 137 & 6 &, 023 & 19,000 &, $000^{\mathrm{b}}$ \\
& Residual &, 042 & 35 &, 001 & & \\
& Total &, 179 & 41 & & & \\
\hline
\end{tabular}

a. Dependent Variable: DACC

b. Predictors: (Constant), TACC, ROA, ACHANGE, RECEIVABLE, LEV, OSHIP

Table 3. t Statistical Test

\begin{tabular}{|c|c|c|c|c|c|}
\hline \multicolumn{6}{|c|}{ Coefficients $^{\mathrm{a}}$} \\
\hline & \multirow[t]{2}{*}{ Model } & \multicolumn{2}{|c|}{$\begin{array}{l}\text { Unstandardized } \\
\text { Coefficients }\end{array}$} & \multirow[t]{2}{*}{$\mathbf{T}$} & \multirow[t]{2}{*}{ Sig. } \\
\hline & & B & Std. Error & & \\
\hline \multirow[t]{7}{*}{1} & (Constant) &,- 047 & ,047 & $-1,000$ & ,324 \\
\hline & ACHANGE & -129 & ,093 & $-1,377$ & 177 \\
\hline & LEV & 207 & ,068 & 3,030 & ,005 \\
\hline & ROA & ,535 & 198 & 2,704 & ,010 \\
\hline & OSHIP & $-2,677$ & 3,665 &,- 731 & 470 \\
\hline & RECEIVABLE &,- 145 & 103 & $-1,406$ & 169 \\
\hline & TACC & ,820 & ,091 & 8,997 & ,000 \\
\hline
\end{tabular}

a. Dependent Variable: DACC 
Based on Table 10, the results of $t$ count variable ACHANGE $=-|1,377|<t$ table $=2,028$ or significance of $0.324>0.05$ which means that there is no significant significance between ACHANGE partially on Financial Statement Fraud (DACC). Thus, hypothesis 2a which states "ACHANGE is partially significant against Fraudulent Financial Statements (DACC) for companies included in the Jakarta Islamic Index (JII) for the 2012-2018 period" is rejected.

Based on Table 10, the results of $\mathrm{t}$ count variable $\mathrm{LEV}=3.030>\mathrm{t}$ table $=$ 2.028 or a significance of $0.005<0.05$, which means that it needs to be compared significantly between LEV partially with Financial Statement Fraud (DACC). Thus hypothesis $2 \mathrm{~b}$ which states that "LEV is a partially significant on Fraud Financial Statements (DACC) in companies included in the Jakarta Islamic Index (JII) for the 2012-2018 period" is accepted.

Based on Table 10, the results of $t$ arithmetic variable $\mathrm{ROA}=2.704>\mathrm{t}$ table $=2.028$ or a significance of $0.010<0.05$ which means that it needs to be compared significantly between ROA partially against Financial Statement Fraud (DACC). Thus, the hypothesis $2_{c}$ which states "ROA is partially significant on Fraudulent Financial Statements (DACC) for companies included in the Jakarta Islamic Index (JII) for the 2012-2018 period" is accepted.

Based on Table 10, the results of the oship variable t count $=-|0.731|<t$ table $=2,028$ or a significance of $0.470<0.05$ which means it does not mean significantly between partial Oship to fraudulent financial statements (DACC). Thus, the $2_{\mathrm{d}}$ which states "Oship partially has a significant effect on fraudulent financial statements (DACC) in the company included in the Jakarta Islamic Index (JII) period 2012-2018" is rejected.

Based on Table 10, the results obtained by the Receivable variable = $|1,406|<$ t table $=2,028$ or significance $0.169>0.05$ which means it does not mean significantly between partial receivables to fraudulent financial statements (DACC). Thus, the hypothesis 3 which states "the industrial nature with proxy can be partially accepted and is not significant to fraudulent 
Iwan Budiyono, Melati Sari Dewi Arum

financial statements (DACC) in the company included in the Jakarta Islamic Index (JII) period 2012-2018" is rejected.

Based on Table 10, the results of the $t$ count TACC $=8,997>t$ table $=2,028$ or $0,000<0.05$ significance which means it should be considered significantly between the TACC partially to fraudulent financial statements (DACC). Thus, the hypothesis 4 which states that "TACC is partially significant to fraudulent financial statements (DACC) in the company included in the Jakarta Islamic Index (JII) period 2012-2018" is accepted.

\section{Simultaneous influence of the variables of ACHANGE, LEV, ROA, OSHIP, RECEIVABLE ANDTACC on financial statement fraud}

The results of hypothesis testing 1 indicating that ACHANGE, LEV, ROA, OSHIP, RECEIVABLE and TACC simultaneously influenced significantly to fraudulent financial statements (DACC) in the company entered in the JII period 2012-2018. The results of the estimated coefficient of determination (adjusted r-square) show the results of Adjusted R-Square of 0.725 or $72.5 \%$. It shows that the contribution of Achange, Lev, ROA, Oship, Receivable and TACC variables affects the fraud of financial statements (DACC) of 0.725 or $72.5 \%$, while $27.5 \%$ are allocated by other factors that are not available in this research model.

\section{Partial influence on financial stability variables using ACHANGE proxyity on financial statement fraud}

The results of the hypothesis test $2_{a}$ show that the variables of the financial risk are proxied with a partial Achange do not have a significant effect on the fraud of financial statements in the companies included in the Jakarta Islamic Index (JII) period 2012-2018. It can happen because it concerns with companies that require monitoring and control responsible for the business system such as finance, as well as management who deals with endangered financial problems by the state, industry and related companies and will change financial report fraud. 
The results of the study showed a negative financial regression coefficient of fraud of financial statements. It is caused by an increase in asset growth numbers every year, the higher the growth rate, the achange which is increasingly large, the opposite, the smaller the level of asset growth, the achange produced is smaller.

\section{Partial influnce of external pressure using LEV proxy on financial statement fraud}

The results of the hypothesis test $2 \mathrm{~b}$ show the external pressure variable with partial LEV proxy has a significant effect on the fraud of financial statements in the company included in the Jakarta Islamic Index (III) period 2012-2018. It is in accordance with the view of Zimbelman et al. (2014: 46). Based on this pressure, managers or executives reduce the need for finance, as stated by Karyono (2013).

Judging from the direction aspect of the influence, indicating LEV partially has a positive effect on fraudulent financial statements, meaning the higher the LEV value, the higher expenses will be to increase fraudulent financial statements. The results of the research are supported by the theory stated by Sulistyawan et al. (2011) which proves that to get a contract with third parties, the creditor who will investigate funds in the company must be pointed by the manager of the company. To add to maximum loans, managers will display the best performance of financial statements.

\section{Partial influence of financial target variable using ROA proxy on financial statement fraud}

The results of the 2 chypothesis test show a financial target variable with a significant partial ROA proxy on the fraud of financial statements in the company included in the Jakarta Islamic Index (JII) period 2012-2018.

It is in line with the theory stated by Karyono (2013) which states that the benefits can be obtained by the company will further increase its share price obtained from management to be published. The higher the ROA value obtained by the company, the higher the company's criteria will get in the 
Iwan Budiyono, Melati Sari Dewi Arum

form of a positive perception of the market. Therefore, Skousen et al. (2009) state that the greater ROA of a company, the greater the level of fraudulent financial statements.

JIAFR | 136

Judging from the direction aspect, it shows that the financial targets that are proxied with ROA partially have a positive effect on the fraud of financial statements, increasing the higher ROA in the company. Then the pressure needed by management will increase, that will cause fraudulent financial statements. It is in accordance with the theory stated by the 316 sectional audit standard that ROA is a profitability ratio used to measure the effectiveness of the company in generating profits by using the acquisition. Profit should be acquired appropriately in order to achieve the agreed profit target to encourage earnings management. Therefore, the company's financial statements will be provided so as not to produce low earnings.

\section{Partial influence of personal financial needs variable by using OSHIP proxy on financial statement fraud}

Based on the $2_{d}$ hypothesis test, the results show the variable of personal financial needs with partially insignificant OSHIP proxy for fraud of financial statements in the company included in the Jakarta Islamic Index (JII) period 2012-2018. It is because during the company's research period the average share ownership ratio by insiders is not too large, which is less than $1 \%$ of shares issued. Companies can be approved not having pressure to increase stock prices and only to add bonuses to executives who have shares less than $1 \%$. It shows a non-conformity with the existing theory. It can be identified that it has no significant interests of personal financial needs that are proxied by OSHIP to fraudulent financial statements.

This research is based on the direction of the influence, each OSHIP rose $1 \%$, the DACC will decrease. It can occur because the greater the share ownership needed by people is interpreted as control in the financial statements (Skousen et al., 2009), so the management of the company is increasingly reliable in presenting financial statements. The higher the 
Determinants in detecting fraud triangle of financial statement on ...

percentage of shareholding of insider, the practice of fraud in manipulating financial statements is reduced.

Partial influence of the nature of industry variable using a proxy RECEIVABLE

financial statement fraud

JIAFR | 137

Based on hypothesis test 3 , the results show that the industrial nature with proxy can be partially accepted which is not significant to fraud of financial statements in the company included in the Jakarta Islamic Index (JII) period 2012-2018. According to Summers and Sweeney (1998), it is because the account is greater than specified by the company based on estimates, for example an unused account and accounted account. However, in this study it has no effect on accounts receivable to fraud of financial statements. It can also cause oversight differences, so managers do not have the opportunity to manipulate financial statements.

The results of this study indicate that account receivable negatively influences the fraud of financial statements. It can happen because the company issued a large bill because there was sales. The company was to pressure income revenues so that non-discretionary produced is small. Small non-discretionary accrual values mean the company uses a decreased earnings strategy, the DACC will tend to decrease when account receivable goes up.

\section{Partial influence on rationalization variables using the total proxy of accrual (TACC) on financial statement fraud}

Based on the hypothesis test 4 , the results show rationalization with a significant total proxy on the fraud of financial statements in the company included in the Jakarta Islamic Index (JII) period 2012-2018.

It is answered with the theory stated by Jones Model (1991) in Sulistyawan (2011) which states that total accruals are used as a source of information on accounting manipulation or earnings management. Skousen et al. (2009) assessed that the variable total accrual ratio can be used for rationalization assessment related to the use of accrual principles by 
management. Therefore, rationalization with total accrual proxies have a significant effect on fraud of financial statements.

From the direction aspect of the interaction, it indicates that rationalization proxied by the total accrual ratio (TACC) has a positive effect on fraud in accordance with the theory proposed by Sulistyawan et al. (2011) which states that the accrual is a difference in earnings with currents. The greater the difference, then the difference is caused by accrual aspects or accounting policies. Income is from accounting policies, while the operating cash flow is only from real cash transactions. The higher the accrual value indicates that there is a strategy to raise profits and the more minus the accrual value indicates there is a profit decline strategy.

\section{Conclusion}

Based on the results of the analysis and discussion that has been carried out, it can be concluded that the fraud triangle in the categories of financial stability, external pressure, financial targets, personal financial needs, opportunity and rationalization simultaneously affect the fraudulent financial statements. Furthermore, financial stability, personal financial needs, and opportunity partially negatively related and have no significant effect on financial statement fraud; while external pressures, financial targets, and rationalization have positive and significant effects on financial statement fraud on companies listed in Jakarta Islamic Index (JII) for period of 20122018.

\section{References}

Arifni, U. (2015). The Effect of Islamic Good Corporate Governance on Profit Sharing Financing through Sharia Compliance, Accounting Analysis Journal, 1-12.

Asrori. (2014). The Implementation of Islamic Corporate Governanceand Its Implication on Syariah bank Performance, Jurnal Dinamika Akuntansi,, 6(1), 90-102. 
Bukair, A. A., \& Rahman, A. (2015). The Effect of the Board of Directors' Characteristics on Corporate Social Responsibility Disclosure by Islamic Banks, Journal of Management Research, 7(2), 506-519.

Davis, J., Schoorman, F., \& Donaldson L. (1997). Toward a Stewardship Theory of Management, Academy of Management Review, 22(1), 20-47.

Ghifari, M. A, Handoko, L. H., \& Yani, E. A. (2015). The Analysis Of Sharia Banking Performance In Indonesia and Malaysia Using The Index Maqashid Approach, Jurnal Ekonomi dan Perbankan Syariah, 3(2), 4766.

Hameed, S., Wirman, A., Alrazi, B., Nazli, M., \& Pramono, S. (2004). Alternative disclosure and performance measures for Islamic Banks, Second Conference on Administrative Sciences: Meeting the Challenges of the Globalization Age,King Fahd University of Petroleum \& Minerals, Dhahran, Saudi Arabia, 19-21. https://doi.org/10.1017/CB09781107415324.004.

Hawary, D. E., Grais, W., 7 Iqbal, Z. (2004). Regulating Islamic financial institutions: The nature of the regulated, World Bank Policy Research Working Paper, 1-49.

Hasanah, U. (2015), The Effect of Compliance with Sharia Principles and Islamic Corporate Governance on Financial Performance in Islamic Commercial Banks, Thesis., Semarang: Universitas Negeri Semarang.

Khasanah, Z., \& Yulianto, A. (2015). Islamic Corporate Governance and Islamic Social Reporting on The Syariah Comercial Bank, Accounting Analysis Journal, 6(4), 1-10.

Rama, A., \& Novela, Y. (2015). Sharia Governance and The Quality of Corporate Governance in The Islamic Banking, Signifikan, 4(2), 111126.

Rifai, A., \& Asrori. (2017). Analysis of Influence of Characteristics of Islamic Supervisory Board toward Islamic Financial Performance. Accounting Analysis Journal, 6(2), 277 - 287.

Sudaryati, D., \& Eskadewi, Y. (2012). The influence of Corporate Governance toward Corporate Social Reponsibility Disclosure in Syaria Banking, Jurnal Ekonomi dan Bisnis, 11(1), 14-28.

Suhendar, C. Y., \& Tanuatmodjo, H. (2014). The Effect of Sharing Profit on Profitability of Sharia Banks, Antologi Pendidikan Akuntansi dan Keuangan, 2(2), 1-6. 
Iwan Budiyono, Melati Sari Dewi Arum

Triyuwono, I. (2007). Mengangkat "Sing Liyan" untuk Formulasi Nilai tambah Syariah. Prosiding of Simposium Nasional Akuntansi X. Makasar: Indonesia.

Usamah. (2010), The Effect of Competence and Syariah Supervisory Board JIAFR | 140 Orgnization Model on Profit Sharing financing in The Syariah banking in Indonesia, Thesis, Semarang: Universitas Diponegoro.

Yulianto, A., \& Solikhah, B. (2016). The Internal Factors of Indonesian Sharia Banking to Predict The Mudharabah Deposits, Review of Integrative Business and Economics Research, 5(1), 210-218.

Zaman, R. M., \& Movassaghi, H. (2002). Interest-Free Islamic Banking: Ideals and Reality, International Journal of Finance, 14(2), 428-244. 